\title{
繰返し曲げを受ける柱要素の軸ひずみの収束現象と発散現象 CONVERGENT AND DIVERGENT BEHAVIOR OF AXIAL STRAIN OF COLUMN ELEMENT SUBJECTED TO CYCLIC BENDING
}

\author{
上谷宏二*, 荒木慶一**, 西本信哉*** \\ Koji UETANI, Yoshikazu ARAKI and Shinya NISHIMOTO
}

\begin{abstract}
It is known that, when a column element is subjected to completely reversed cyclic bending under a constant axial force, the hysteretic behavior of its axial strain is classified into two classes: one is convergent behavior to a steady state and the other, divergent behavior. In this paper, based on the steady-state limit theory, the critical amplitude of curvature, which bounds the two classes of the axial strain behavior, is found as a steady-state limit. The steady-state limit is predicted as the first limit point of the steady-state path, which represents the sequence of steady states generated under monotonically and continuously increased curvature amplitude.
\end{abstract}

\section{Keywords : convergent behavior, divergent behavior, elasto-plastic column element, axial strain, cyclic bending, steady-state limit 収束現象，発散現象，弾塑性柱要素，軸ひずみ，繰返し曲げ，定常状態限界}

\section{1. 序}

建築構造物がますます高層化, 大スパン化を要求されている現 在において，その中心である鋼構造物の耐震及び耐風設計に際し， 各部材の繰返し塑性変形時の勒性性能をいかに評価し，設計に反映 させるかは重要な研究課題である。

一定軸力下で繰返し曲げを受ける柱材については多数の研究が 行われ, 軸力值と曲げ振幅值の組合わせがある限界を越えると,

(1) 圧縮軸方向変形, (2) 載荷構面内の 2 次的たわみモード, (3) 載荷構面外変形などの変形が累積・発散し, 復元力特性及び耐力の 劣化が生じることが知られている1)。

圧縮軸方向変形に関しては, ひずみ硬化が進行する限り柱要素 の軸ひずみはある一定値に収束するが2-5)，完全弾塑性材料の場 合 ${ }^{3-6)}$ や局部座屈等に起因するひずみ軟化特性を持つ場合 ${ }^{7,8)}$ に は，軸力值と曲げ振幅値の組合わせがある限界を越えると，軸ひず みが限りなく発散することが既に報告されている。完全弾塑性材 料で構成された柱材を対象として，この収束と発散を隔てる限界

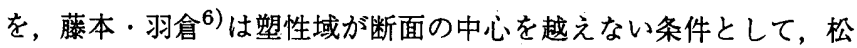
井・三谷 ${ }^{4)}$ は材軸ひずみの収束值が存在するための条件として，近 藤ら ${ }^{5)}$ は振幅を増加させた時に材軸ひずみが降伏ひずみに達する条 件として求めている。しかし，これらの研究で提示された限界条件 は，いずれも限られた条件下でのみ適用されるもので，任意の材料
特性や断面を持つ柱材に対して，限界をとらえることができる一般 的手法を提示したものではない。

一方, 著者らは一定軸力下で繰返し曲げを受ける柱材の挙動 が, 同一の周期挙動を繰り返す定常状態への収束挙動か, 座屈モー ドのような 2 次的モードの発散挙動に大別される事に着目し，こ れらの挙動を隔てる限界を予測する理論として対称限界理論及び定 常状態限界理論を展開してきた ${ }^{9-11)}$ 。また, 横座屈のような載荷 構面外への変形が初めて生じる限界振幅值が存在することを理論的 に予測し，この限界を初めて求めた ${ }^{12)}$ 。

対称限界理論及び定常状態限界理論では，振幅を連続的に単調 増加させた時の定常状態の変化を追跡し, この変化を定常状態経 路として表し, 経路の分岐点や極限点としてこれらの限界を予測す る。よって, 対象とする構造物の形状や材料特性に関わらず, 数学 的に明確な臨界点として限界を記述することができる。

本論文では, 繰返し載荷を受ける柱材の軸ひずみの累積現象に着 目し，材料がひずみ軟化特性を持つ場合も含め, 収束現象と発散現 象を隔てる限界を定常状態限界理論により予測できることを示す。 また弾塑性履歴挙動解析を行い, 限界前後における挙動の特性や, 一方向載荷時の挙動との相違点を明らかにする。第 2 章及び第 3 章では閉型解を得ることが可能な単純モデルを用いて解析を行い, その性質を明らかにし，第 4 章では，より現実的なモデルについ て数值解析を行い, 単純モデルで得られた結果との対応を調べる。
* 京都大学大学院工学研究科建築学専攻 教授 : 工博

** 京都大学大学院工学研究科建築学専攻 大学院生.工修

*** 大成建設秼構造設計部 工修
Prof., Dept of Architecture, Kyoto Univ, Dr. Eng.

Graduate Student, Dept. of Architecture, Kyoto Univ., M. Eng. Structural Design and Proposal Dept., Taisei Corporation, M. Eng. 

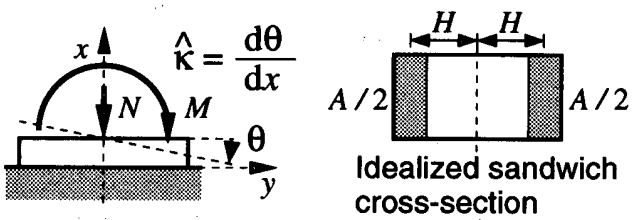

図 1 解析モデル

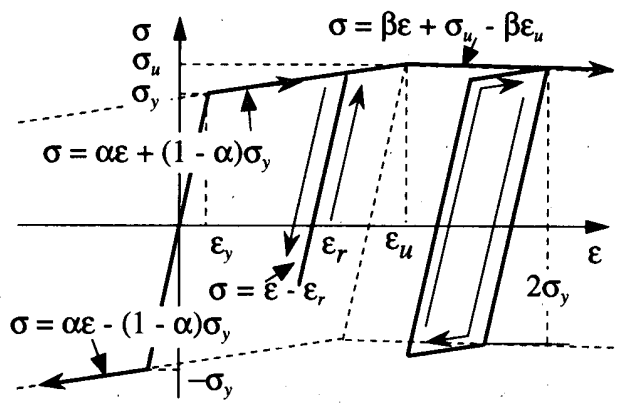

図 2 無次元化応力 -ひずみ関係

\section{2. 定常状態限界理論解}

定常状態限界理論の基本概念，基本方針を簡単にまとめ, 理想 化サンドウィッチ断面に離散化した柱要素に対して変化率方程式を 誘導し, 定常状態限界を求める。

\section{1 解析モデル}

図 1 に示す, 一定軸力 $N$ の下で振幅 $\Phi$ の曲率 $\hat{\kappa}$ を受ける柱の 微小要素を解析対象とする。面内挙動のみを扱い面外変形を考慮し ない。平面保持を仮定し，そり・せん断変形を無視する。微小ひず みを仮定する。

応力 $\hat{\sigma}$, ひずみ $\varepsilon$ 及び軸力 $N$ は，いづれも圧䌅を正方向とし， 鉛直方向上向き及び水平方向右向きを，それぞれ $x, y$ 軸の正の方 向とする。 $x$ 軸から時計回りの方向への回転角を $\theta$ で表す。この 時 $\hat{\kappa}=\mathrm{d} \theta / \mathrm{d} x$ となる。

理想化サンドウィッチ断面に離散化し，フランジ間距離 $2 H$ を 用いて曲率 $\hat{\kappa}$ と曲率振幅 $\Phi$ を無次元化する。

$$
\kappa=\hat{\kappa} H, \quad \phi=\Phi H
$$

また, ヤング係数 $E$ と断面積 $A$ を用いて軸力 $N$ と応力 $\hat{\sigma}$, 降伏 応力 $\hat{\sigma}_{y}$, 圧縮強さ $\hat{\sigma}_{u}$ を無次元化する。

$$
n=\frac{N}{E A}, \quad \sigma=\frac{\hat{\sigma}}{E}, \quad \sigma_{y}=\frac{\hat{\sigma}_{y}}{E}, \quad \sigma_{u}=\frac{\hat{\sigma}_{u}}{E}
$$

右側と左側のフランジの状態量を，それぞれ（ $)_{\mathrm{R}},()_{\mathrm{L}}$ で表し, 釣合式 (3) とひずみ - 変位関係式 (4) を示す。

$$
\begin{gathered}
n=\frac{\sigma_{\mathrm{R}}+\sigma_{\mathrm{L}}}{2} \\
\kappa=\frac{\varepsilon_{\mathrm{R}}-\varepsilon_{\mathrm{L}}}{2}
\end{gathered}
$$

各フランジは, 文献 4) と類似の圧縮側トリリニア，引張側バイ リニアとする応力ーひずみ関係注1) に従う (図 2 )。材料は, 繰返 し軟化又は繰返し硬化現象および疲学現象を呈することがないと

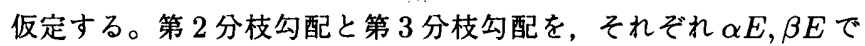
表す。この $\alpha, \beta$ と, 降伏ひずみ $\varepsilon_{y}$, 圧維強さに達する時のひずみ

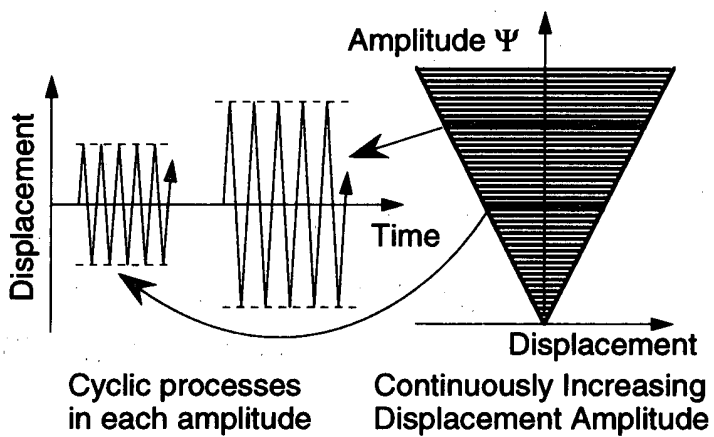

図 3 載荷プログラム COIDA

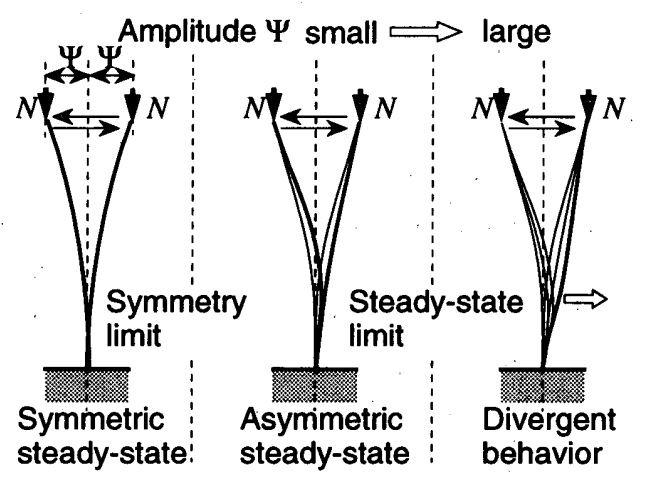

図 4 対称限界と定常状態限界

$\varepsilon_{u}$, 残留塑性ひずみ $\varepsilon_{\boldsymbol{r}}$ を用いて無次元化応力 - ひずみ関係式を以 下に示す。

$$
\begin{aligned}
\text { 弾性応答 : } & \sigma=\varepsilon \\
\text { 圧縮側第2分枝上の応答 : } & \sigma=\alpha \varepsilon+(1-\alpha) \sigma_{y} \\
\text { 引張側第2分枝上の応答 : } & \sigma=\alpha \varepsilon-(1-\alpha) \sigma_{y} \\
\text { 第3分枝上の応答 : } & \sigma=\beta \varepsilon+\sigma_{u}-\beta \varepsilon_{u} \\
\text { 除荷過程応答 : } & \sigma=\varepsilon-\varepsilon_{r}
\end{aligned}
$$

第 2 分枝勾配 $\alpha$ の符号は正とし，第 3 分枝勾配 $\beta$ の符号を正又 は負の值とする事により，ひずみ硬化やひずみ軟化が柱要素の挙動 に及はす影響を調べる。

\section{2 定常状息限界理論の基本概念と基本方針}

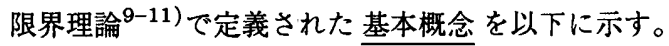

1. 各振幅レベルで定常状態に収束するまで振幅 $\Psi$ の繰り返し載 荷を行い，その後に $\Psi$ を連続的に単調增加させる載荷プログ ラム $\mathrm{COIDA}^{9,10)}$ を定義する(図 3 )。

2. COIDA に従う強制変位を図 4 の片持梁 - 柱に与えると, 反 転時の変形状態が初期材軸線に関して対称な対称定常状態か ら，この対称性を有しない非対称定常状態へ移行する。この限 界は対称限界と呼ばれる。さらに振幅を増加させると, 非対称 定常状態への収束挙動から発散挙動へ移行する限界が存在す る。この限界が定常状態限界と呼ばれる。

3. 釣合状態を表す点の軌跡が鈞合経路と呼ばれるのにならい, 定 常状態を表す点の軌跡は定常状態経路と呼ばれる。本論文で は，定常状態経路の経路パラメ夕を $\tau, \tau$ による微分を(j)で 表す。 


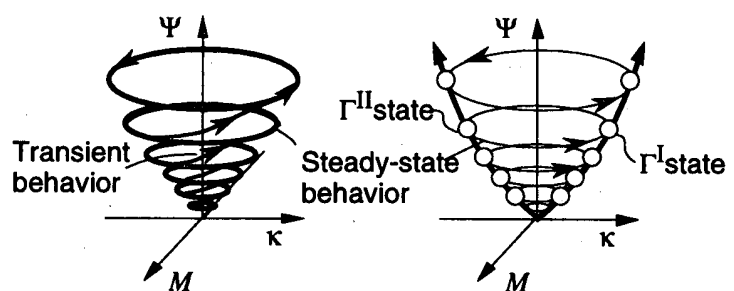

$\begin{array}{lll}\text { (1) Elasto-plastic hysteretic (2) Steady-state limit theory } & \text { (2) }\end{array}$ behavior analysis

図 5 履歴挙動解析と定常状態限界理論

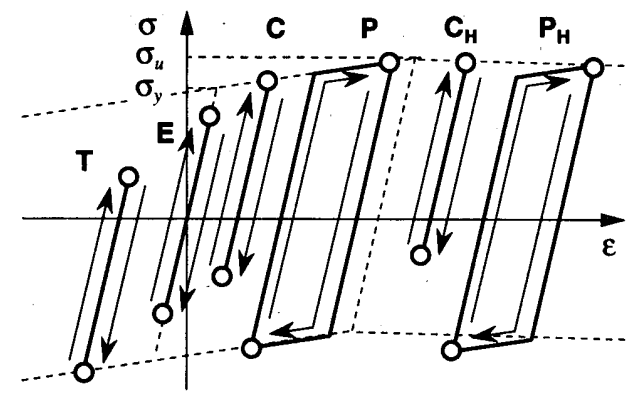

図 6 応力・ひずみ周期挙動の分類

4. 制御変位の正側と負側の反転時状態は, それぞれ $\Gamma^{\mathrm{I}}$ 状態, $\Gamma^{\mathrm{II}}$ 状態と呼ばれる (図 5 )。

定常状態限界理論の 基本方針を以下にまとめる。

1. 定常状態経路を増分解析により追跡し, 経路の極限点として定 常状態限界を予測する。

2. 定常状態とその変化率だけに着目して定常状態の変化を追跡 する。つまり, 定常状態に収束した後の状態量のみについて定 式化を行う。これより, 定常状態限界理論では, ある定常状態 から振幅を増加させた時に, 次の定常状態に収束するまでの 過渡過程における複雑な履歴挙動の全てを追跡する必要がな w。

3. 定常状態に収束した後において, 各フランジのひずみの進行 方向が反転するのは, 制御変位の進行方向が反転する瞬間のみ であると仮定し注2)，制御変位の反転時状態である $\Gamma^{\mathrm{I}}$ 状態と

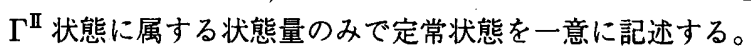

\section{3 定常状態変化率方程式}

釣合式 (3) とひずみ - 変位関係式 $(4)$ は $\Gamma^{\mathrm{I}}$ 及び $\Gamma^{\mathrm{II}}$ 状態でも成 立する。以下では $\Gamma^{\mathrm{I}}, \Gamma^{\mathbb{I I}}$ 状態に属する状態量を，それぞれ上添字 の I, II を用いて表す。完全両振り曲げの条件: $\kappa^{\mathrm{I}}=\phi, \kappa^{\mathrm{II}}=-\phi$ を 考慮し, これらの式を定常状態経路パラメタ $\tau$ に関して微分する ことにより次式を得る。

$$
\begin{aligned}
& 0=\frac{\dot{\sigma}_{\mathrm{R}}^{\mathrm{I}}+\dot{\sigma}_{\mathrm{L}}^{\mathrm{I}}}{2}, \quad 0=\frac{\dot{\sigma}_{\mathrm{R}}^{\mathrm{II}}+\dot{\sigma}_{\mathrm{L}}^{\mathrm{II}}}{2}, \\
& \dot{\phi}=\frac{\dot{\varepsilon}_{\mathrm{R}}^{\mathrm{I}}-\dot{\varepsilon}_{\mathrm{L}}^{\mathrm{I}}}{2},
\end{aligned}
$$

応力 -ひずみ周期挙動は図 6 の 6 種類に分類される。圧縮側と 引張側の反転時におけるひずみの值が与えられていれば, 全ての周 期挙動は一意に記述することができる。フランジのひずみの圧維側 及び引張側反転時における状態量を，それぞれ ( ) $)^{c}$ 及び ()$^{t}$ で表す と, 変化率関係式は式 (12)の形で表される注3)。

$$
\dot{\sigma}^{c}=d_{c c} \dot{\varepsilon}^{c}+d_{c t} \dot{\varepsilon}^{t}, \quad \dot{\sigma}^{t}=d_{t c} \dot{\varepsilon}^{c}+d_{t t} \dot{\varepsilon}^{t}
$$

表 1 応力 - ひずみ周期挙動の変化

\begin{tabular}{cccccc}
\hline type & strain rate & $d_{c c}$ & $d_{c t}$ & $d_{t c}$ & $d_{t t}$ \\
\hline $\mathrm{E}$ & & 1 & 0 & 0 & 1 \\
$\mathrm{C}$ & $\dot{\varepsilon}^{c} \geq 0$ & $\alpha$ & 0 & $\alpha-1$ & 1 \\
$\mathrm{C}$ & $\dot{\varepsilon}^{c}<0$ & 1 & 0 & 0 & 1 \\
$\mathrm{~T}$ & $\dot{\varepsilon}^{t} \leq 0$ & 1 & $\alpha-1$ & 0 & $\alpha$ \\
$\mathrm{T}$ & $\dot{\varepsilon}^{t}>0$ & 1 & 0 & 0 & 1 \\
$\mathrm{P}$ & & $\alpha$ & 0 & 0 & $\alpha$ \\
$\mathrm{C}_{\mathrm{H}}$ & $\dot{\varepsilon}^{c} \geq 0$ & $\beta$ & 0 & $\beta-1$ & 1 \\
$\mathrm{C}_{\mathrm{H}}$ & $\dot{\varepsilon}^{c}<0$ & 1 & 0 & 0 & 1 \\
$\mathrm{P}_{\mathrm{H}}$ & $\dot{\varepsilon}^{c} \geq 0$ & $\beta$ & 0 & $\beta-\alpha$ & $\alpha$ \\
$\mathrm{P}_{\mathrm{H}}$ & $\dot{\varepsilon}^{c}<0$ & $\alpha$ & 0 & 0 & $\alpha$ \\
\hline
\end{tabular}

式 (12) の係数を表 1 に示す。これらの係数は現在の応力 -ひずみ の周期挙動の種類，及び現在の状態からのひずみ恋化率の符号に よって決定される。

定常状態限界理論では，基本方針で示した通り，制御変位の反転 時における状態量のみで定常状態が記述される。そのために, 各フ ランジのひずみの反転時における状態量は, 式 (13), (14)のいづ れかを用いて $\Gamma^{\mathrm{I}}, \Gamma^{\mathrm{II}}$ 状態における状態量と対応づけられる。

$$
\begin{aligned}
& ()^{c}=()^{\mathrm{I}} \text { and }()^{t}=()^{\mathrm{II}} \\
& ()^{c}=()^{\mathrm{II}} \text { and }()^{t}=()^{\mathrm{I}}
\end{aligned}
$$

式 (13)(14) を用いて式 (12) の添字を置き換えた式と, 式 (10)(11) を連立させ定常状態変化率方程式を得る。

\section{4 解析結果}

変化率方程式を解いて得られた変化率解を, 曲率振幅 $\phi$ に関し て積分し、トータル量の解を得る。定常状態における左右フランジ の周期挙動の組合せは $n$ と $\phi$ の值に依存する。この分類を図 7 に 示す。各領域に対する解を以下に示す。なお, いづれの解において も，応力とひずみについては式 (15) の関係が常に成立した。

$$
()^{c}=()_{R}^{\mathrm{I}}=()_{L}^{\mathrm{I}}, \quad()^{t}=()_{L}^{\mathrm{I}}=()_{R}^{\mathrm{I}}
$$

\section{第三分枝勾配が正の場合:}

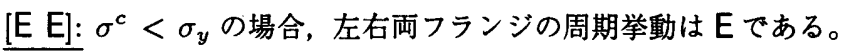
この領域を [E E] とあらわす。[]内の文字は, それぞれ, 左右の フランジの周期挙動のパターンをあらわす。この領域での解を以下 に示す。

$$
\begin{array}{ll}
\sigma^{c}=n+\phi, & \sigma^{t}=n-\phi, \\
\varepsilon^{c}=n+\phi, & \varepsilon^{t}=n-\phi
\end{array}
$$

よって [E E] の領域は $n+\phi<\sigma_{y}$ により決定される。

$[\mathrm{C} \mathrm{C}]: n+\phi \geq \sigma_{y}$ なら [E E] から [C C]へ移る。

$$
\begin{array}{rlrl}
\sigma^{c} & =n+\phi, & & \sigma^{t}=n-\phi, \\
\varepsilon^{c}=\frac{n+\phi-\bar{\sigma}_{y}}{\alpha}, & \varepsilon^{t}=\frac{n+(1-2 \alpha) \phi-\bar{\sigma}_{y}}{\alpha}
\end{array}
$$

ここで $\bar{\sigma}_{y}=(1-\alpha) \sigma_{y}$ とおいた。[C C] の挙動を呈する条件式 $\sigma^{c}<\sigma_{u}, \sigma^{c}-\sigma^{t}<2 \sigma_{y}$ より，[C C] 領域を与える式 $n+\phi<$ $\sigma_{u}, \quad \phi<\sigma_{y}$ を得る。

$\left[\mathrm{C}_{\mathrm{H}} \mathrm{C}_{\mathrm{H}}\right]: n+\phi \geq \sigma_{u}$ を満たすと, $[\mathrm{C} \mathrm{C}]$ から $\left[\mathrm{C}_{\mathrm{H}} \mathrm{C}_{\mathrm{H}}\right]$ に移行す

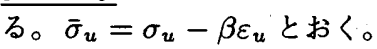

$$
\begin{array}{rlrl}
\sigma^{c} & =n+\phi, & \sigma^{t} & =n-\phi, \\
\varepsilon^{c} & =\frac{n+\phi-\bar{\sigma}_{u}}{\beta}, & \varepsilon^{t} & =\frac{n+(1-2 \beta) \phi-\bar{\sigma}_{u}}{\beta} \\
\sigma^{c}-\sigma^{t} & <2 \sigma_{y} \text { より } \phi<\sigma_{y} \text { を得る。 }
\end{array}
$$



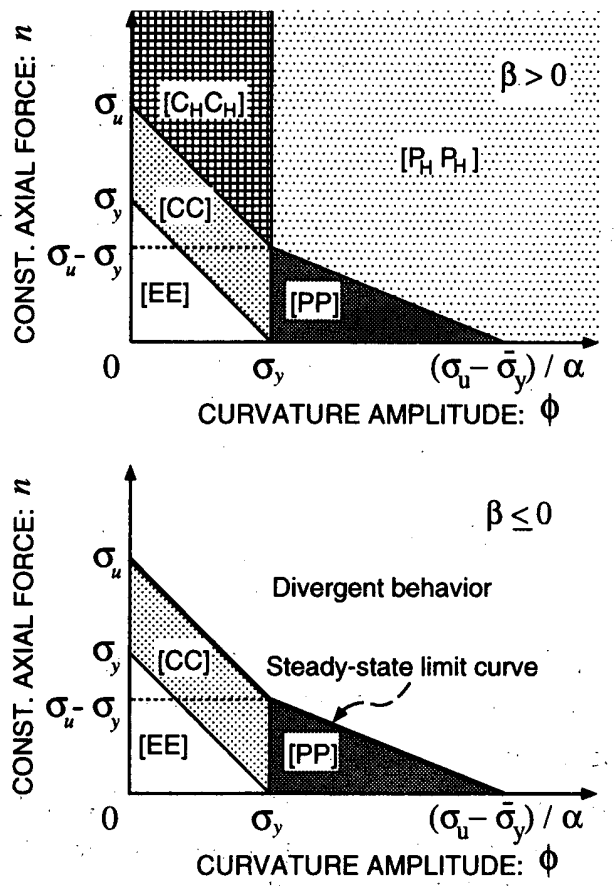

図 7 領域の分類図

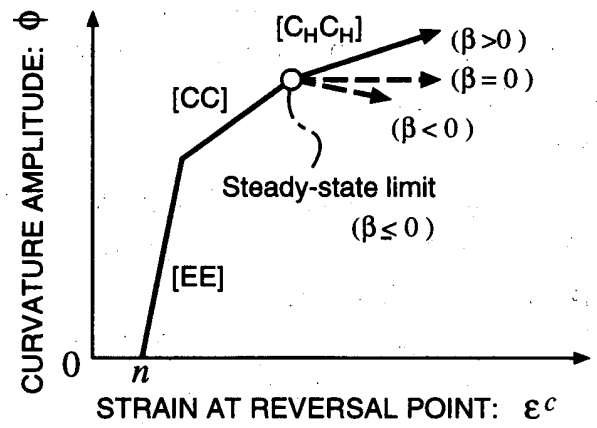

図 8 定常状態経路と定常状態限界

$[\mathrm{PP}]: \phi \geq \sigma_{y}$ で [C C] から [P P ] に移行する。

$$
\begin{array}{lll}
\sigma^{c}=n+\alpha \phi+\bar{\sigma}_{y}, & & \sigma^{t}=n-\alpha \phi-\bar{\sigma}_{y}, \\
\varepsilon^{c}=\frac{n}{\alpha}+\phi, & \varepsilon^{t}=\frac{n}{\alpha}-\phi
\end{array}
$$

$\sigma^{c}<\sigma_{u}$ よりこの領域の式 $n+\alpha \phi+\bar{\sigma}_{y}<\sigma_{u}$ を得る。

$\left[\mathrm{P}_{\mathrm{H}} \mathrm{P}_{\mathrm{H}}\right]: \phi \geq \sigma_{y}$ の条件で $\left[\mathrm{C}_{\mathrm{H}} \mathrm{C}_{\mathrm{H}}\right]$ 加， $n+\alpha \phi+\bar{\sigma}_{y} \geq \sigma_{u}$ の 条件で $[\mathrm{P} P]$ から，それぞれ $\left[\mathrm{P}_{\mathrm{H}} \mathrm{P}_{\mathrm{H}}\right]$ に移行する。 $\gamma=\alpha-2 \beta$ と おいて以下の解を得る。

$$
\begin{gathered}
\sigma^{c}=n+\alpha \phi+\bar{\sigma}_{y}, \quad \sigma^{t}=n-\alpha \phi-\bar{\sigma}_{y}, \\
\varepsilon^{c}=\frac{n+\alpha \phi-\bar{\sigma}_{u}+\bar{\sigma}_{y}}{\beta}, \quad \varepsilon^{t}=\frac{n+\gamma \phi-\bar{\sigma}_{u}+\bar{\sigma}_{y}}{\beta}
\end{gathered}
$$

第三分枝勾配が 0 または負の場合:

$\left[\mathrm{C}_{\mathrm{H}} \mathrm{C}_{\mathrm{H}}\right]$ と $\left[\mathrm{P}_{\mathrm{H}} \mathrm{P}_{\mathrm{H}}\right]$ の領域では， $\beta=0$ ならばひずみが不定と なり， $\beta<0$ ならば振幅が増加する方向に解が存在しない。 $\beta \leq$ 0 の場合, 定常状態経路の極限点として定常状態限界の予湘解が得 られる(図 8 )。

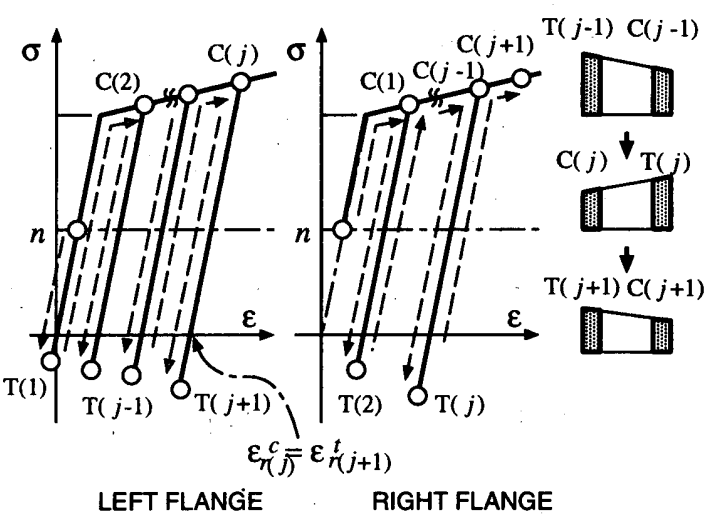

図 9 左右フランジの挙動

\section{3. 弾望性履歷挙動解析}

本章では，前章と同一のモデルを用いて，一定軸力下で一定振 幅絽り返し曲げを受ける柱要素の履歴挙動を，制御曲率の反転時に 関する漸化式を立てて定式化し, 前章で求めた定常状態限界理論解 との関係を調べる。

\section{1 反転時における状態量の定義}

漸化式を立てるために，反転時における状態量について定義を 行う(図 9 )。本章では, 1 回目の曲げを時計回り方向に与えると する。1 回目の曲率の反転時における右側と左側のフランジの状 態を,それぞれ, $\mathrm{C}(1) \cdot \mathrm{T}(1)$ と呼ぶ。また, 2 回目の反転時に おける右側と左側のフランジの状態を，それぞれ， $\mathrm{T}(2) \cdot \mathrm{C}(2)$ と呼ぶ。以降, この繰返しを行う。反転数を $j$, サイクル数を $k て ゙$ 表すと, $\mathrm{C}(j=2 k-1)$ と $\mathrm{T}(j=2 k)$ は右フランジの反転時状態を 表し， $\mathrm{C}(j=2 k)$ と $\mathrm{T}(j=2 k-1)$ は左側の反転時状態を表す。

$\mathrm{C}(j)$ と $\mathrm{T}(j)$ に属する状態量を，それぞれ ()$_{(j)}^{c}$ と ()$_{(j)}^{t}$ であら わすと, 釣合式 $(3)$ とひずみ - 変位関係式 $(4)$ より，第 $j$ 反転時に おいて以下の式が成立する。

$$
\begin{aligned}
& n=\frac{\sigma_{(j)}^{c}+\sigma_{(j)}^{t}}{2} \\
& \phi=\frac{\varepsilon_{(j)}^{c}-\varepsilon_{(j)}^{t}}{2}
\end{aligned}
$$

\section{2 漸化式と解の分類}

各フランジの応力ーひずみ状態点の動きは，一定軸力が正の場 合, 以下の 5 種類に分類できる。本節では分類に応じて漸化式を 立て, その解を示す。

1. 弾性域

2. 圧縮側反転時に状態点が第 2 分枝上に存在する

(a)引張側反転時に弾性挙動域にある

(b) 引張側反転時にひずみ硬化線上に存在する

3. 圧縮側反転時に状態点が第 3 分枝上に存在する

(a)引張側反転時に弾性挙動域にある

（b）引張側反転時にひずみ硬化線上に存在する

第三分枝勾配が正の場合:

1. 弾性域: 左右両フランジとも弾性挙動を呈する場合, 式 (5)よ り以下の式が成立する。

$$
\sigma_{(j)}^{c}=\varepsilon_{(j)}^{c}, \quad \sigma_{(j)}^{t}=\varepsilon_{(j)}^{t}
$$


式 (21), 式 (22) と式 (23) より次の解を得る。

$$
\sigma_{(j)}^{c}=\varepsilon_{(j)}^{c}=n+\phi, \quad \sigma_{(j)}^{t}=\varepsilon_{(j)}^{t}=n-\phi
$$

この挙動を呈する条件式を以下に示す。

$$
n+\phi<\sigma_{y}
$$

2.-(a): $\sigma_{(j)}^{c}=n+\phi \geq \sigma_{y}$ ならば, 圧縮側反転時の応力は第 2 分枝上に存在する。第 $j+1$ 反転時において, 式 (21) 及び式 (22) と, 圧縮側フランジで式 (6), 引張側フランジで式 (9) が成立し, 第 $j$ 反転時の圧縮側フランジで式 (6) と式 (9) が成立すること, 及 び図 9 から

$$
\varepsilon_{r(j)}^{c}=\varepsilon_{r(j+1)}^{t}
$$

が成立することより，以下の漸化式を得る。

$$
\varepsilon_{(j+1)}^{c}=\frac{1-\alpha}{1+\alpha} \varepsilon_{(j)}^{c}+2 \frac{n+\phi-\bar{\sigma}_{y}}{1+\alpha}
$$

漸化式の解は,

$\varepsilon_{(j)}^{c}=\frac{n+\phi-\bar{\sigma}_{y}}{\alpha}+\left(\varepsilon_{(1)}^{c}-\frac{n+\phi-\bar{\sigma}_{y}}{\alpha}\right)\left(\frac{1-\alpha}{1+\alpha}\right)^{j-1}$

となり，その収束値，すなわち $j \rightarrow \infty$ の極限值は

$$
\varepsilon_{(\infty)}^{c}=\lim _{j \rightarrow \infty} \varepsilon_{(j)}^{c}=\frac{n+\phi-\bar{\sigma}_{y}}{\alpha}
$$

となる。式 (6) と式 (21) より応力の極限值を得る。

$$
\sigma_{(\infty)}^{c}=n+\phi, \quad \sigma_{(\infty)}^{t}=n-\phi
$$

$\sigma_{(\infty)}^{c}-\sigma_{(\infty)}^{t}=2 \phi \geq 2 \sigma_{y}$ を満たすと 2.-(b)に, $\sigma_{(\infty)}^{c}=n+\phi \geq$ $\sigma_{u}$ を满たすと 3.-(a)に移行する。

2.-(b): 第 $j$ 反転時において, 式 (21) および式 (22) が成立し, 圧縮側フランジで式 (6), 引張側フランジで式 (7) が成立すること より，以下の解を得る。

$$
\begin{array}{ll}
\sigma_{(j)}^{c}=n+\alpha \phi+\bar{\sigma}_{y}, & \sigma_{(j)}^{t}=n-\alpha \phi-\bar{\sigma}_{y}, \\
\varepsilon_{(j)}^{c}=\frac{n}{\alpha}+\phi, & \varepsilon_{(j)}^{t}=\frac{n}{\alpha}-\phi
\end{array}
$$

$\sigma_{(j)}^{c}=n+\alpha \phi+\bar{\sigma}_{y} \geq \sigma_{u}$ なら 3.-(b) の挙動を呈する。

3.-(a)：2.-(a) と同様の方法で漸化式を導くことができる。 $\bar{\sigma}_{y} を$ $\bar{\sigma}_{u}$ に変更し， $\alpha$ を $\beta$ に変更すれば良い。第 $h$ 反転時において， 初めて 3.-(a) の挙動に移行したとすると, 漸化式の解は以下のよ うに求められる。

$$
\varepsilon_{(j)}^{c}=\frac{n+\phi-\bar{\sigma}_{u}}{\beta}+\left(\varepsilon_{(h)}^{c}-\frac{n+\phi-\bar{\sigma}_{u}}{\beta}\right)\left(\frac{1-\beta}{1+\beta}\right)^{j-h}
$$

この収束値を以下に示す。

$$
\varepsilon_{(\infty)}^{c}=\frac{n+\phi-\bar{\sigma}_{u}}{\beta}
$$

また，応力の収束值は以下の通りである。

$$
\sigma_{(\infty)}^{c}=n+\phi, \quad \sigma_{(\infty)}^{t}=n-\phi
$$

$\sigma_{(\infty)}^{c}-\sigma_{(\infty)}^{t}=2 \phi \geq 2 \sigma_{y}$ なら 3.-(b) に移行する。

3.-(b): 第 $j+1$ 反転時において, 式 (21) および式 (22) と, 圧縮 側フランジで式 (8) が成立すること, および, 引張側フランジで

$$
\sigma_{(j+1)}^{t}=\alpha \varepsilon_{(j+1)}^{t}+(\beta-\alpha) \varepsilon_{(j)}^{c}+\bar{\sigma}_{u}-2 \bar{\sigma}_{y}
$$

が成立すること(図 2 ) より，以下の漸化式を得る。

$$
\varepsilon_{(j+1)}^{c}=\frac{\alpha-\beta}{\alpha+\beta} \varepsilon_{(j)}^{c}+2 \frac{n+\alpha \phi-\bar{\sigma}_{u}+\bar{\sigma}_{y}}{\alpha+\beta}
$$

第 $h$ 反転時に第 3 分枝上へ達した時の解を示す。

$$
\begin{aligned}
\varepsilon_{(j)}^{c}= & \frac{n+\alpha \phi-\bar{\sigma}_{u}+\bar{\sigma}_{y}}{\beta} \\
& +\left(\varepsilon_{(h)}^{c}-\frac{n+\alpha \phi-\bar{\sigma}_{u}+\bar{\sigma}_{y}}{\beta}\right)\left(\frac{\alpha-\beta}{\alpha+\beta}\right)^{j-h}
\end{aligned}
$$

この収束値は

$$
\varepsilon_{(\infty)}^{c}=\frac{n+\alpha \phi-\bar{\sigma}_{u}+\bar{\sigma}_{y}}{\beta}
$$

となる。また，応力の収束値は以下の通りである。

$$
\sigma_{(\infty)}^{c}=n+\bar{\sigma}_{y}+\alpha \phi, \quad \sigma_{(\infty)}^{t}=n-\bar{\sigma}_{y}-\alpha \phi
$$

\section{第三分枝勾配が 0 の場合:}

圧縮側反転時に応力 - ひずみ状態点が第 3 分枝上に存在する 3 . の場合のみ漸化式及び解が異なる。

3.-(a): 第 $j+1$ 反転時で式 (21) および式 (22), 引張側フランジ で式 (9) が成立し，また，圧縮側フランジで

$$
\sigma_{(j+1)}^{c}=\sigma_{u}=\varepsilon_{(j)}^{c}-\varepsilon_{r(j)}^{c}
$$

を満たすことと式 $(26)$ より以下の式が得られる。

$$
\varepsilon_{(j+1)}^{c}-\varepsilon_{(j)}^{c}=2\left(n+\phi-\sigma_{u}\right)
$$

$\sigma_{(j)}^{c}-\sigma_{(j)}^{t} \geq 2 \sigma_{y}$, つまり $n \leq \sigma_{u}-\sigma_{y}$ を満たす場合, 3.-(b) の 挙動を呈する。

3.-(b): 第 $j+1$ 反転時に式 (21) および式 (22) が成立し, 引張 側フランジが式 (35), 圧縮側フランジが $\sigma_{(j+1)}^{c}=\sigma_{u}$ を満たすこ と, 及び第 $j$ 反転時で圧縮側フランジで $\sigma_{(j)}^{c}=\sigma_{u}$ を渵足し, 式 (8) が成立することより以下の式が得られる。

$$
\varepsilon_{(j+1)}^{c}-\varepsilon_{(j)}^{c}=2 \frac{n+\alpha \phi-\sigma_{u}+\bar{\sigma}_{y}}{\alpha}
$$

これらの結果より $\beta=0$ ならば, いづれの場合も圧縮側フランジ のひずみが等差級数的に発散する。

\section{第三分枝勾配が負の場合:}

3.-(a) の漸化式の解は式 (32) に一致し， $\beta<0$ より公比が 1 より大きくなるので, 軸ひずみは等比級数的に発散する。しかし,

3.-(b) 式 (37) の場合は, 解を誘導できるものの非常に複雑な形に なる。よって本論文では閉型解を得ることを行わず，4章の数值 解析によりその性質を調べる。

本節での履歴挙動解析結果と前章の定常状態理論に基づく解析 結果との比較を以下にまとめる。(1)一定振幅が定常状態限界以下 ならば軸ひずみは収束し，この収束值は定常状態限界理論による予 測値と完全に一致する。(2) 一定振幅が定常状態限界以上の場合, 第 3 分枝勾配 $\beta$ が 0 ならばサイクル数に対して等差級数的に, $\beta$ が負ならば等比級数的に発散する。

\section{3 一方向載荷時との比較}

第 3 分枝勾配が 0 及び負の場合について, 制御曲率を一方向に 単調増加させた時に, 最大耐力となる点の曲率 $\kappa_{m}$ 注4) と, 定常 状態限界 $\phi_{\boldsymbol{c} r}$ の比較を図 10 に示す。

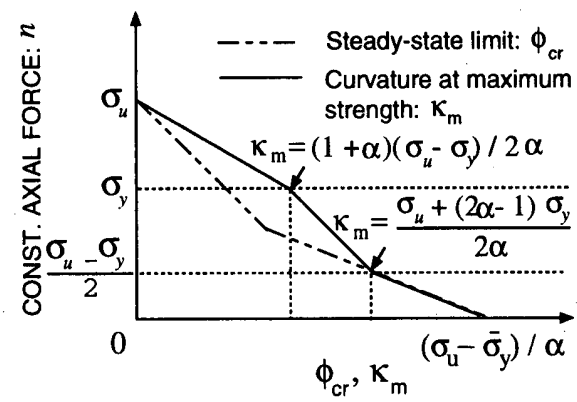

図 10 一方向載荷時と繰返し載荷時の比較 
$0 \leq n<\left(\sigma_{u}-\sigma_{y}\right) / 2$ の場合は, $\kappa_{m}$ と $\phi_{c r}$ が一致する。 $\left(\sigma_{u}-\right.$ $\left.\sigma_{y}\right) / 2 \leq n<\sigma_{y}$ の場合は一定軸力 $n$ と曲率 $\kappa_{m}$ が

$$
n+\kappa_{m}=\frac{(1+\alpha) \sigma_{u}-\bar{\sigma}_{y}}{2 \alpha}
$$

の関係を满たす。また $\sigma_{y} \leq n<\sigma_{u}$ の場合，引張側フランジは一 度降伏した後に弾性除荷しており，次式を満たす。

$$
\sigma_{(1)}^{t}=\varepsilon_{(1)}^{t}-\frac{(\alpha-1) n+\bar{\sigma}_{y}}{\alpha}
$$

よって, $n$ と $\kappa_{m}$ の関係は以下に示す通りである。

$$
n+\frac{2 \alpha}{1+\alpha} \kappa_{m}=\sigma_{u}
$$

図 10 は, $\left(\sigma_{u}-\sigma_{y}\right) / 2 \leq n<\sigma_{u}$ の場合，一方向載荷条件下で 最大耐力に達する時の曲率以下の振幅で繰返し曲げを与えた場合に も，軸ひずみが発散する事を示す。

\section{4. 多数ファイバーモデルの数值解析例}

多数ファイバー断面を用いて層方向に柱要素を離散化し, 数值 解析を行う。これより単純モデルで得られた閉型解と,より現実的 なモデルの数值解を比較する。

\section{1 解析モデル}

図 11 に示す角型鋼管柱の微小要素を解析対象とする。断面を 6 層に領域分割する。，層方向の分割数のみが 2 章の解析モデルと異 なる。 $i$ 番目のファイバーの断面積 $a_{i}$ と重心位置 $y_{i}$ を図 11 中に 示す。断面諸量と材料特性の数值データを表 2 に示す注5)。

材軸ひずみ $\varepsilon_{A}$, 曲率 $\hat{\kappa}$ と各ファイバーのひずみ $\varepsilon_{i}$ の間で式 $(46)$ の関係式が成立する。

$$
\varepsilon_{i}=\varepsilon_{A}+\hat{\kappa} y_{i}
$$

また，以下の釣合式 (47) が成立する。

$$
N=\sum_{i=1}^{6} a_{i} \hat{\sigma}_{i}
$$

\section{2 定常状態限界理論解}

第 3 分枝勾配 $\beta$ が $\beta=\beta_{1}(=0)$ と $\beta=\beta_{2}(<0)$ の場合につ いて定常状態限界理論解を数值的に求める。解析結果を図 12 に示 す。ここで, 降伏軸力を $N_{y}$ で表し, 軸力 $N=0$ で曲率を単調増 加させた時の弾性限曲率を $\hat{\kappa}_{y}\left(5.19481 \times 10^{-5} \mathrm{~cm}^{-1}\right)$ で表した。

また, 定常状態限界における応力 - ひずみ周期挙動のパターン の分布をファイバー $1,2,3($ 図 11 ) について，それぞれ同図中の [ ] 内に左から順に示す。いづれの場合においても，この分布は $y=0$ の面に関して対称であった。材料がひずみ軟化特性を持つ場合に は，断面中にひずみ硬化が進行している部分が存在するにも関わら ず定常状態限界に達した。

表 2 断面諸量と材料特性

\begin{tabular}{lll}
\hline \multicolumn{1}{c}{ データ名 } & & 数値データ \\
\hline 断面積 & $A$ & $1.10000 \times 10^{3}\left(\mathrm{~cm}^{2}\right)$ \\
断面 2 次モーメント & $I$ & $5.59167 \times 10^{5}\left(\mathrm{~cm}^{4}\right)$ \\
塑性断面係数 & $Z_{p}$ & $2.27500 \times 10^{4}\left(\mathrm{~cm}^{3}\right)$ \\
ヤング係数 & $E$ & $2.05939 \times 10^{2}(\mathrm{GPa})$ \\
降伏応力 & $\sigma_{y}$ & $2.94200 \times 10^{2}(\mathrm{MPa})$ \\
压縮強さ & $\sigma_{u}$ & $3.08909 \times 10^{2}(\mathrm{MPa})$ \\
第 2 分枝勾配 & $\alpha$ & $1.00000 \times 10^{-2}$ \\
第 3 分枝勾配 & $\beta_{1}(=0)$ & 0.00000 \\
第 3 分枝勾配 & $\beta_{2}(<0)$ & $-1.20000 \times 10^{-2}$ \\
\hline
\end{tabular}

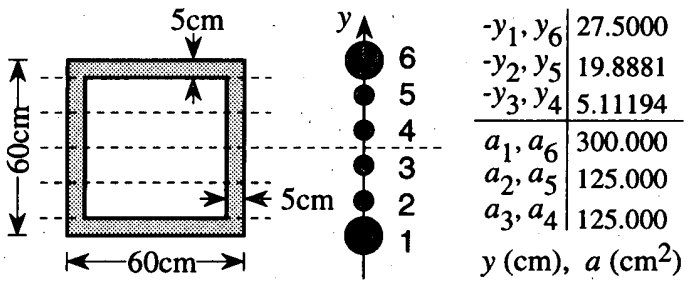

図 11 数値解析モデルの層方向の離散化
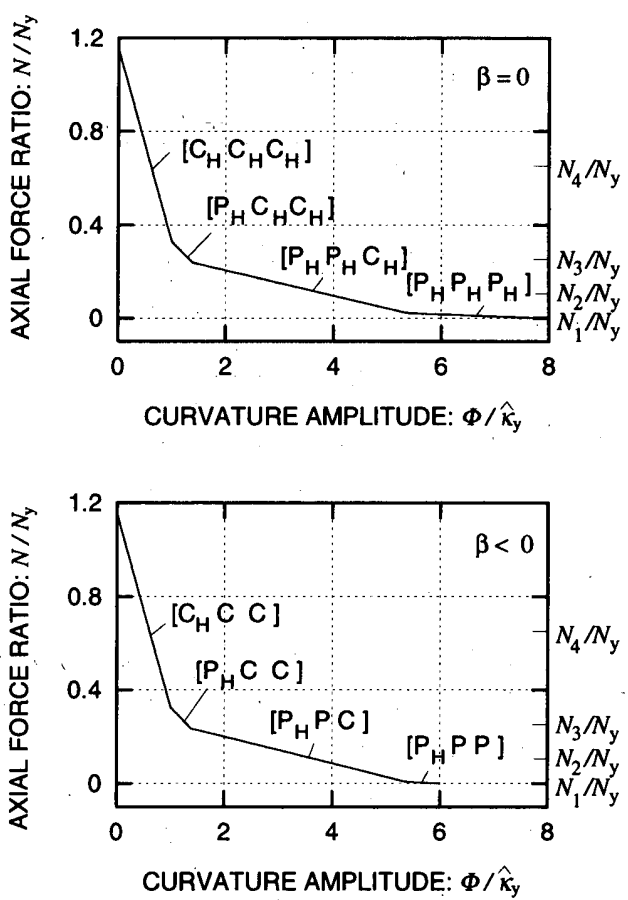

図 12 定常状態限界曲線

\section{3 弾塑性履歷挙動解析}

第 3 分枝勾配 $\beta$ が $\beta_{1}$ と $\beta_{2}$ の場合の定常状態限界理論解を, そ れぞれ $\Phi_{c r}^{1}$ と $\Phi_{c r}^{2}$ で表し，これらの值の $99 \%$ と $101 \%$ の定振 幅繰返し曲げを与える時の履歴挙動の全てを, 通常の弾塑性解析 により数值的に追跡する。定常状態限界時の塑性域の分布に応じ て，4 種類の軸力 $N$ の下で解析を行う。 $N$ と $\Phi_{c r}^{1}, \Phi_{c r}^{2}$ の組合せ を表 3 に示す。

材軸ひずみ $\varepsilon_{A}$ - サイクル数 $j$ 関係を, 図 13 と図 14 に示す。い づれの解析においても, 収束判定式 (48) 又は変形制限式 (49) を満 たす場合に解析を終了した。 $\delta_{1}, \delta_{2}$ は解析者が決める定数である。

$$
\begin{gathered}
\left|\frac{\varepsilon_{1(j)}^{c}-\varepsilon_{1(j-1)}^{c}}{\varepsilon_{1(j)}^{c}}\right|<\delta_{1} \\
\frac{\varepsilon_{1(j)}^{c}}{\varepsilon_{y}}<\delta_{2}
\end{gathered}
$$

表 3 各軸力における定常状態限界理論解

\begin{tabular}{llll}
\hline & $N / N_{y}$ & $\Phi_{c r}^{1} / \hat{\kappa}_{y}$ & $\Phi_{c r}^{2} / \hat{\kappa}_{y}$ \\
\hline$N_{1}$ & 0.00000 & 7.97803 & 5.99999 \\
$N_{2}$ & 0.10333 & 3.68152 & 3.50539 \\
$N_{3}$ & 0.25333 & 1.21032 & 1.19633 \\
$N_{4}$ & 0.66667 & 0.50971 & 0.50803 \\
\hline
\end{tabular}



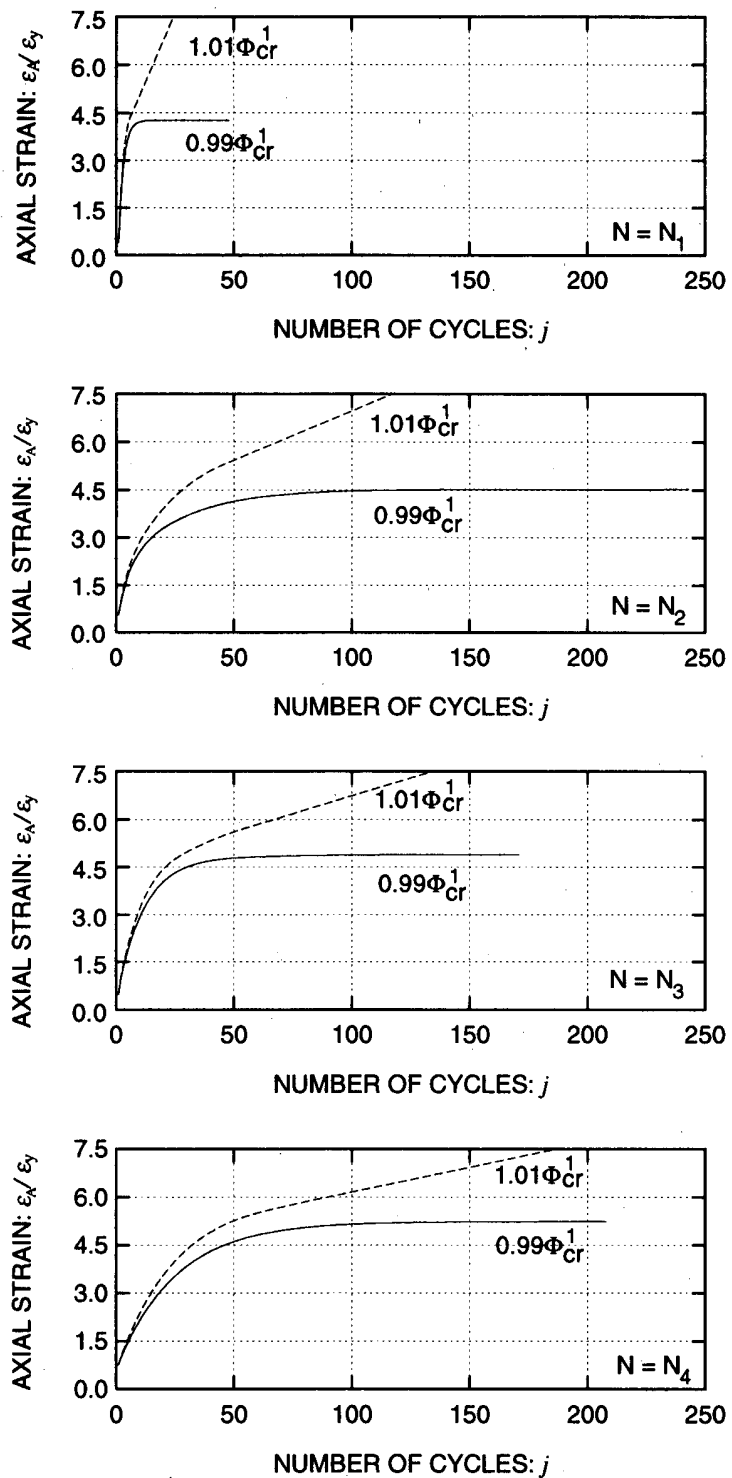

図 13 軸ひずみーサイクル数関係 $(\beta=0)$
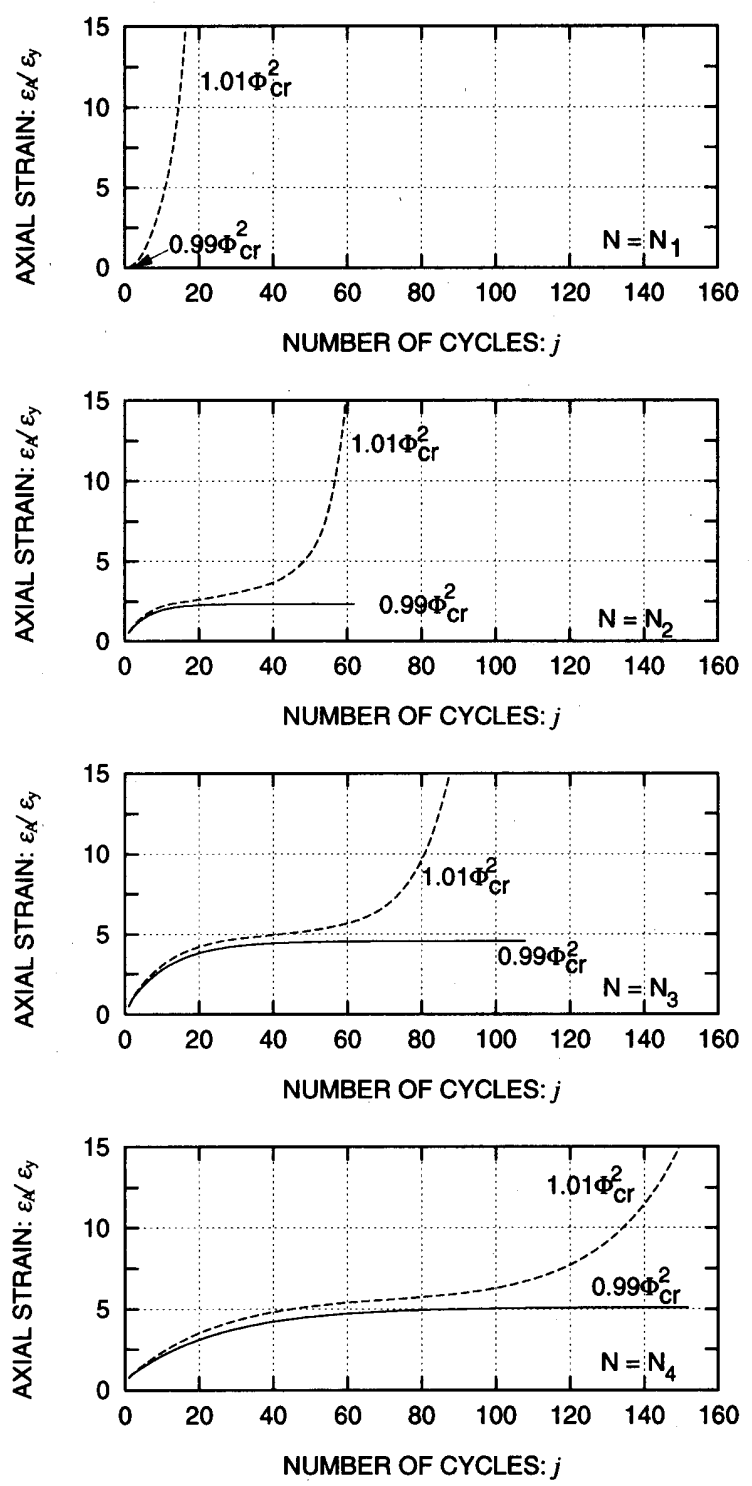

図 14 軸ひずみーサイクル数関係 $(\beta<0)$
いづれの条件式も，断面の左端ファイバーのひずみ $\varepsilon_{1}$ を用いて定 めた。 $\varepsilon_{1(j)}^{c}$ は, 第 $j$ サイクル圧縮側反転時におけるひずみを表 し， $\varepsilon_{y}$ は降伏ひずみを表す。

図 13 と図 14 は, 第 3 分枝勾配 $\beta$ がそれぞれ 0 と負の時の結果 であり, 図 13 では $\varepsilon_{A} / \varepsilon_{y} \leq 7.5$, 図 14 では $\varepsilon_{A} / \varepsilon_{y} \leq 15$ までの 関係を表した。いづれの解析でも $\delta_{1}=1.0 \times 10^{-5}$ とした。

また， $\delta_{1}=1.0 \times 10^{-8}$ として履歴挙動解析から得られたひずみ の収束値を $\varepsilon_{1 c v}^{c}$ で表し, 表 4 に示す。定常状態限界理論から予測 されたひずみの収束値を $\varepsilon_{1}^{c} て ゙$ 表すと, 以下に示す相対誤差 $e$ は, いづれの場合においても， $1.0 \times 10^{-6}$ 以下であった。

$$
e=\frac{\varepsilon_{1}^{c}-\varepsilon_{1 c v}^{c}}{\varepsilon_{1}^{c}}
$$

さらに，材軸ひずみが発散する時の復元力特性の変化を調べる 事を目的として，限界の $110 \%$ の一定振幅で繰返し曲げを与えた 時の挙動を追跡する。一例として $N=N_{3}$ について, $\delta_{2}=30$ として解析を行う。モーメントー回転角関係を図 15 に示す。図中 の $M_{y}$ は軸力 0 時の弾性限モーメントを表す。第 3 分枝勾配 $\beta$ が 0 の場合は， 16 サイクルで最大耐力に達し，その後は，変形制限
を満たす 118 サイクルまで変化はなかった。これに対して $\beta<0$ の場合 12 サイクルで最大耐力に達し, 変形制限を満たす 39 サイ クルまで復元力特性と最大耐力は劣化し続けた。

本節での数值解析結果より以下の結論を得た。(1)3.2 節で得ら れた 2 つの結論が, より現実的な多数ファイバー断面モデルにお いても十分な精度で成立する。(2) 第 3 分枝勾配 $\beta$ が $\beta=0$ の場 合, 復元力特性及び耐力は劣化しないが, $\beta<0$ の場合, これら が急激に劣化する。また，第 3 章で省略した， $\beta<0$ で応力 - ひ ずみ状態点がループを描く場合にも，軸方向ひずみが等比級数的に 発散することを例証した(図 $14 N=N_{1}$ )。

\section{表 4 ひずみの収束値 $\varepsilon_{1 c v}$}

\begin{tabular}{ccc}
\hline 軸力 & $\varepsilon_{1 c v}^{c}\left(\Phi=0.99 \Phi_{c r}^{1}\right)$ & $\varepsilon_{1 c v}^{c}\left(\Phi=0.99 \Phi_{c r}^{2}\right)$ \\
\hline$N_{1}$ & $1.73801 \times 10^{-2}$ & $8.48571 \times 10^{-3}$ \\
$N_{2}$ & $1.16684 \times 10^{-2}$ & $8.31190 \times 10^{-3}$ \\
$N_{3}$ & $8.69843 \times 10^{-3}$ & $8.20476 \times 10^{-3}$ \\
$N_{4}$ & $8.20254 \times 10^{-3}$ & $8.02381 \times 10^{-3}$ \\
\hline
\end{tabular}



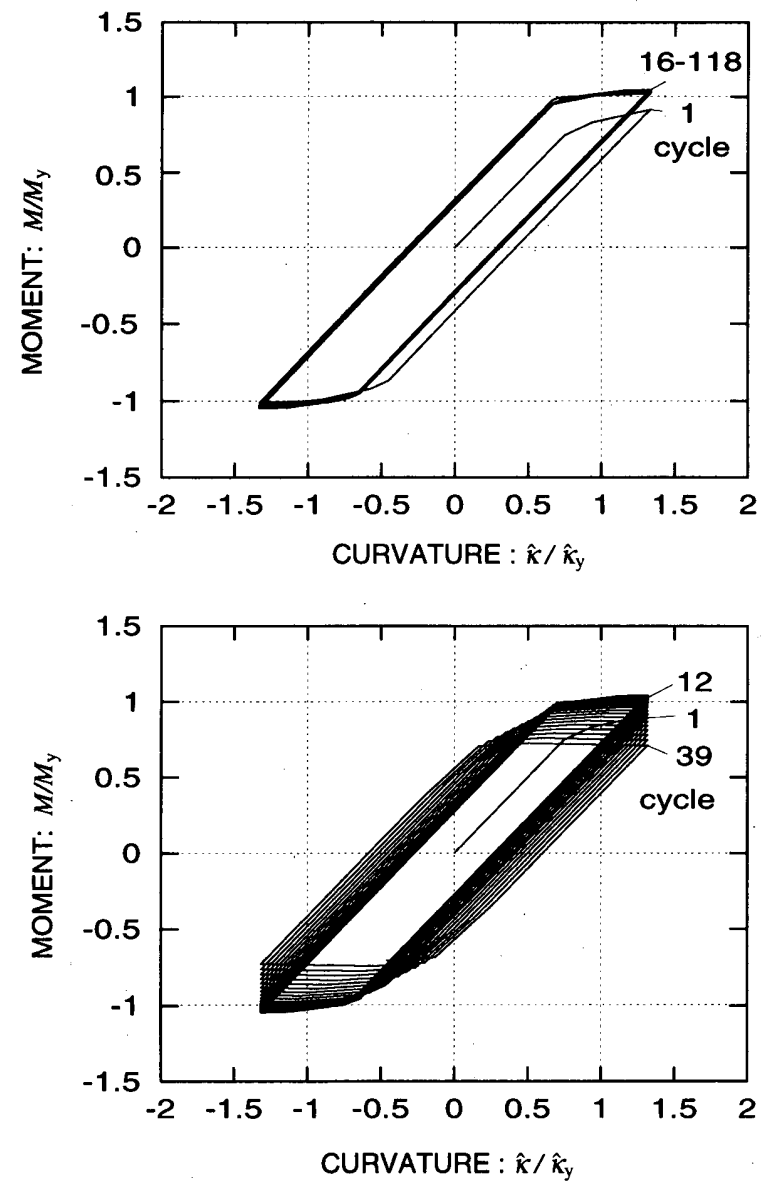

図 15 モーメントー回転角関係 $\left(N=N_{3}\right)$

\section{5. 結論}

一定軸力下で完全両振り繰返し曲げを受ける柱要素の軸ひずみ の収束現象と発散現象について, 定常状態限界理論に基づく解析と 弾塑性履歴挙動解析を行い、以下の成果を得た。

1. 理想化サンドウィ・ッチ断面を用いて柱要素を単純モデル化 し, 定常状態限界理論に基づく理論的解析を行い, 定常状態 限界の閉型解を得た。定常状態限界理論では，振幅を連続的 に単調増加させた時の定常状態の変化を追跡し,この変化を 表す定常状態経路の極限点として, 定常状態への収束挙動か ら発散挙動へ移行する限界である定常状態限界を, 数学的に 明確な臨界点として記述できる。

2. 上記 1. と同一のモデルに対して，一定振幅繰り返し曲げを受 ける柱要素の軸ひずみの挙動を, 制御曲率の反転時における 状態量に関する漸化式として定式化し，以下の事項を明らか にした。（1）振幅が定常状態限界以下の場合に漸化式の解は 収束し, その収束值は定常状態限界理論による予測値と一致 する。(2) 振幅が定常状態限界以上の場合, 軸ひずみは等差 級数的又は等比級数的に発散する。(3) 単調載荷条件下で最 大耐力に達する時の曲率以下の振幅で繰返し曲げを与える場 合にも，軸ひずみが発散する可能性がある。

3. 多数ファイバー断面を用いて柱要素を層方向に離散化し, 定 常状態限界理論に基づく数值解析を行い, 定常状態限界理 論解を数值的に求めた。材料がひずみ軟化特性を持つ場合に は，ひずみ硬化が進行している領域が存在していても，定常
状態限界に達する場合がある。このような場合には, 既往の 研究4-6) で提示されている手法では，限界を直接予測するこ とはできない。また，この限界の上下の一定振幅で繰返し曲 げを与えた時の履歴挙動の全てを, 弾塑性履歴挙動解析によ り数值的に追跡した。これらの解析の結果より, 単純モデル で明らかにした事項が，より現実的な多数ファイバー断面に おいても成立することを示し，任意の材料特性や断面を持つ 柱材の限界を, 定常状態限界理論によりとらえられることを 例証した。

\section{謝辞}

本研究にご助力を頂いた熊代 美徳君 (京阪電気鉄道) に謝意を表します。

注

注 1) 本論文では，一例として，ひずみ軟化を考慮した応力ーひずみ関係 を仮定した。しかし，仮定する応力ーひずみ関係によって解析結果 は異なるので，解析対象に応じてこれを変更する必要がある。

注 2) 本論文第 2,3,4 章における例題では，この仮定が成立することを履 歴挙動解析により確認している。しかし，この仮定が成立しない場 合もあり，その場合にも限界を予測することが可能な手法の基本ア イディアを, 文献 13)に発表している。

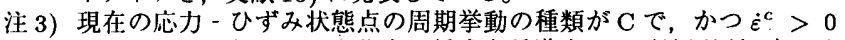
の場合を一例として，変化率関係式を誘導する。压縮側反転時では 式 (6) と式 (9)を同時に満たすので, これらの式を定常状態経路パ ラメータテで微分して以下の式を得る。

$$
\dot{\sigma}^{c}=\alpha \dot{\varepsilon}^{c}=\dot{\varepsilon}^{c}-\dot{\varepsilon}_{r}
$$

また、引張側反転時では以下の式を満たす。

$$
\dot{\sigma}^{t}=\dot{\varepsilon}^{t}-\dot{\varepsilon}_{r}
$$

上式から $\dot{\varepsilon}_{r}$ を消去して変化率関係式を得る。

$$
\dot{\sigma}^{c}=\alpha \dot{\varepsilon}^{c}, \quad \dot{\sigma}^{t}=(\alpha-1) \dot{\varepsilon}^{c}+\dot{\varepsilon}^{t}
$$

注 4) 曲率 (変位) を指定しているので，モーメント(力) を指定した場合 の釣合経路上の安定限界とは異なる。

注 5） $\beta$ についてパラメトリック解析を行うことが目的ではないので, 一 例として $\beta_{2}$ の数値を定めた。

参考文献

1) 日本建築学会: 鋼構造座屈設計指針, 第 5.4 章 繰り返し載荷を受ける柱 材, pp. 170-183, 1996.1

2) 山田稔, 白川潔：軸圧を受ける H 型鋼柱の弾塑性曲げ変形性状に関す る研究 (II: 交番繰り返し曲げ: 曲げモーメントー曲率関係), 日本建築 学会論文報告集, No. 141 , pp. 29-35, 1967.11

3) S. Igarashi, C. Matsui, K. Yoshimura, and K. Matsumura: Inelastic behavior of structural steel sections under alternative loadings (2) Final state of resisting moment and experimental study, Trans. A.I.J., No. 170 , pp. $39-48,1970.11$

4）松井千秋，三谷勲：繰返し水平力を受ける高張力鋼骨組の弾塑性性状に 関する研究，日本建築学会論文報告集，No. 250, pp. 31-40, 1976.12

5) 近藤一夫, 王学鋒, 中倉健介, 花井正実: 繰り返し変動曲げを受ける鋼 柱の弾塑性・崩壊挙動, 日本建築学会構造系論文報告集, No. 434, pp. 59-74, 1992.4

6) 藤本盛久, 羽倉弘人: 繰返し荷重を受ける鉄骨断面の弾塑性解析に関 する研究 (第 2 報), 日本建築学会論文報告集, No. 121, pp. 14-18, 1966.3

7）牧野稔, 松井千秋, 三谷勲: $\mathrm{H}$ 型鋼柱の局部座屈後の変形性状 その 1 実 験計画および実験結果, 日本建築学会論文報告集, No. 281, pp. 71-80, 1979.7

8) Yasuhiro Uchida and Shosuke Morino: Limit of axial force ratio for degrading steel beam-columns involving local buckling, Journal Struct. Constr. Eng., AIJ, No. 425, pp. 57-68, 1991.7

9) K. Uetani and Tsuneyoshi Nakamura: Symmetry limit theory for cantilever beam-columns subjected to cyclic reversed bending, $J$. Mech. Phys. Solids, Vol. 31, No. 6, pp. 449-484, 1983

10) 上谷宏二: 繰り返し両振り曲げを受ける弾塑性梁一柱についての対称 限界理論と定常状態限界理諭, 博士論文, 京都大学, 1984.11

11) 上谷宏二: 繰り返し両振り曲げを受ける片持梁 - 柱の定常状態限界理論 （その1），日本建築学会棈造系論文報告集, 第 428 号, pp. 105-115, 1992.8

12）上谷宏二, 中村恒善, 常岡次郎: 繰返し両振り曲げを受ける片持梁 - 柱 の構面外変形発生機構と臨界点理論, 日本建築学会大会学術講演梗概 集, 構造 II, pp. 1077-1078, 1988

13）荒木 慶一, 上谷宏二: 任意形状平面骨組の対称限界解析法（歪反転に 関する制約の除去)，日本建築学会大会学術講演梗概集, 構造 I, pp. $1311-1312,1994$

（1996年 7 月10日原䅭受理，1996年12月12日採用決定） 